\title{
水利水电工程设计中的水土保持理念
}

\author{
左昌毅 \\ 广西钱江水利水电有限公司 \\ DOI:10.32629/hwr.v4i5.2997
}

[ 摘 要] 在国内的现代化建设过程中,水土保持理念的应用是一项利国利民的举措。随着可持续发展深入人心,水利水电工程设计中也引入环 保理念, 降低工程建设对周边环境的影响。把水土保持理念应用到水利工程设计中,能够减少水土流失,减少对环境的破坏,对于生态水利的建设 具有重要意义。本文对水利水电工程设计中水土保持理念的应用进行了分析。

[关键词] 水利水电; 工程设计; 水土保持理念

\section{1 水利水电工程水土流失的特点及表现}

1.1 水坝、水库等工程, 占地面积大、建设周期长是水坝、水库等工 程的典型特点。此外施工条件严峻, 施工工序复杂、易受各种因素影响 也是此类工程容易造成水土流失的原因。水利水电工程往往需要大面积 的平整土地, 而在对原有土地情况的改变过程中, 若不采取相应的防护 措施, 致使大量土地裸露在外, 自身抗侵蚀能力受到影响, 将会引发严重 的水土流失。

1.2 线性水利水电工程。灌渠、河道和管道等工程是线性水利水电工 程的主要表现形式, 此类工程长度较长, 因此需要建立大量的配套设施, 包 括取料场、弃渣场、拦水坝和蓄水池等。因此水土流失在整个工程沿线都 有可能发生, 对其的控制也比较难进行。因此对于不同的水利水电施工工 程, 应该结合实际情况制定针对性的预防措施。

\section{2 水土保持理念的概念及实施原则}

水土保持是集土壤学、水文学和生态学等于一体的一个专业名词, 顾 名思义是保持水土资源。水土保持的理念即在我国的施工建设的过程中, 应该将水土的保护和工程建设进行有效的结合, 防止因为建设导致当地的 水土流失, 破坏其原有的生态环境, 影响当地民众的生活。水土保持的理念 的出发点是好的, 但是在实施相关的方法的时候, 应该根据一定的原则, 而 不是盲目性的。首先要对水土保持的理念提出的目的进行深入的了解, 就 水土保持的相关知识进行学习, 了解水土保持和水土分布, 就施工的过程 中可能会遇到的问题进行分析, 做好相应的准备工作, 根据不同地区的水 土结构制定好相应的方案。

\section{3 水土保持理念在水利水电建设中的应用}

3. 1 应用在水土流失预测中

在工程实施之前, 施工人员会对当地的水土区域进行划分, 了解水土 流失的种类, 从而对水土流失种类进行预测, 这便是水土保持理念的实施 前提。水利水电工程庞大, 势必会大面积开挖地基及排水措施, 这样会增大 水土流失的风险。因此, 在施工之前必须对工程对环境的破坏程度有一定 的预测, 制定出合理的水土流失预防措施, 降低水土流失的发生几率, 减少 财产损失。并对废渣废屑填充于沟内, 尽可能恢复至最初模样, 或者选择当 地适宜的植物类型种植于上面, 这样可以极大程度的地保护水土, 降低水 土流失的概率。

3. 2 应用于生态环境的保护中

现如今伴随着我国经济持续的进行发展, 人们对绿色生态环境要求的 提升, 在水利水电工程中, 施工的时候必须要充分的去考虑对生态环境的 影响, 要引起足够的重视, 这也是可以促进水土保持理念的良好落实。因为 影响水土流失的因素比较多, 并且极端环境也不可进行避免的, 只有从直
观上尽可能的避免水土流失的情况出现, 不断的提高水平, 同时指导植被 得到合理的重视, 避免过度浪费用地的使用。此外在进行施工中, 需要对施 工人员进行严格的监督, 在工程技术后利用资源做好压实保护处理, 将其 一些杂物进行清理, 避免环境受到破坏。

3. 3应用于工程设计结构中

挖填土地时挖土量减少, 设计为挖掘时不破坏地面。例如, 设计水库大 坝时, 地方的土壤质量和地形等条件可以满足设计要求, 并在选择大坝类 型时选择合理的大坝类型。然后通过检查坝体土方量和破坏土地的挖掘, 使设计方案合理。设计项目的水线时, 应合理设计深细的水线段和高填充 的水线。如果设计者需要设计多个方案, 则可以比较和对比方案, 然后选择 最佳的挖掘和高填充方案。如果修理工程投资增加, 地质勘探等多种因素 可以控制的情况下, 应该选择隧道方案。这在建设期间对土地的破坏较小。 而且, 挖掘时挖掘的土方量也不多, 控制着土方流失。

3. 4 应用于水土保持的善后工作

在堆放工程弃渣时, 要先建设好防护栏和挡渣墙, 然后才能弃渣, 谨 防弃渣流失加剧水土流失。在水利水电工程建设完毕后, 一定要拆除工 程下游的围堰, 不能等它自行溃烂, 因为围堰自溃会留下很多废渣, 造成 水土流失。另外, 施工队还必须承担起施工结束后的植被恢复工作, 把占 用的农田、林区全部返还, 并进行植被的修复, 降低对环境的破坏程度。 发挥水利水电工程对水土的保护作用, 水利水电工程对水土的保护是防 治水土流失最有效的方法之一, 施工队在建设水利水电工程时要引进高 科技和高质量的原材料, 提高水利水电工程的防洪抗灾能力, 从而有效 地阻止水土流失。

\section{4 结语}

水土保持是指对自然因素和人为活动造成水土流失所采取的预防和 治理措施, 我国是世界上水土流失比较严重的国家之一, 因此, 水土保持一 直是我们国家所提倡鼓励的政策。水利工程建设过程中的水土保持设计必 须要尽可能减少土地资源的占用破坏以及植被破坏等问题, 同时还应该考 虑到水利工程建设后期的运营管理, 为后期的生态环境修复、景观塑造创 造一个良好的条件。

\section{[参考文献]}

[1]陈炎松.水利水电工程设计中的水土保持理念[J].科技创新与应 用,2018(28):94-95.

[2]陈玉英.水电工程水土保持方案编制有关问题探讨 [ J].水利技术监 督,2001(06):42-43.

[3]李佳萱.基于水土保持理念的水利水电工程设计 [J].建材与装 饰,2019(20):285-286. 